\title{
PENGEMBANGAN PRODUK TABLET ORAL DISINTEGRASI PIROKSIKAM
}

\section{PRODUCT DEVELOPMENT OF PYROXICAM ORALLY DISINTEGRATING TABLET}

\author{
Rohmiati, Iis Wahyuningsih*, Any Guntarti, Iin Narwanti, Hilma Putri, \\ Shinta Desy Anwar, Firda Rahmadani, Tedi Rustandi, Muhamad Rido Islamy \\ Program Profesi Apoteker, Fakultas Farmasi, Universitas Ahmad Dahlan, Jl. Prof. Soepomo, \\ Janturan, Warungboto, Yogyakarta 55164, Indonesia \\ *Penulis Korepondensi, email: iis.wahyuningsih@pharm.uad.ac.id
}

\begin{abstract}
ABSTRAK
Piroksikam digunakan sebagai analgetik dan antiinflamasi yang sering dialami oleh kalangan lansia yang mempunyai kesulitan menelan. Salah satu upaya yang dapat dilakukan untuk mengatasi masalah tersebut yaitu dengan sediaan Orally Disintegrating Tablet (ODT). Avicel PH 102 merupakan bahan disintegran yang biasa digunakan sebagai penyusun ODT, karena mempunyai daya disintegran yang sangat baik. Tujuan penelitian ini untuk mengembangkan piroksikam menjadi bentuk sediaan ODT. Metode pembuatan ODT dilakukan dengan metode kempa langsung. Variasi konsentrasi Avicel PH 102 yang digunakan untuk formula 1 sebesar 15\% dan formula 2 sebesar $20 \%$. Tablet hasil formulasi diperiksa karakteristik fisik yang meliputi identifikasi tablet, kerapuhan, kekerasan, ketebalan, waktu hancur, bentuk dan ukuran tablet, laju disolusinya serta dilakukan penetapan kadar. Metode analisa kadar piroksikam baik pada penentuan disolusi maupun pada penentuan kadar, dilakukan verifikasi metode spektrofotometri UV-Vis terlebih dahulu meliputi spesifisitas, presisi, dan akurasi. Formula terbaik selanjutnya dilakukan uji hedonik. Hasil verifikasi untuk ketiga uji memenuhi persyaratan sehingga dikatakan metode uji valid. Hasil uji fisik tablet dikatakan memenuhi syarat kecuali untuk uji kerapuhan. Data laju disolusi dan penetapan kadar tablet piroksikam memenuhi syarat FI V yaitu laju disolusi tidak kurang dari $75 \%(\mathrm{Q}+5 \%)$ dan hasil penetapan kadar F1 dan F2 berturut-urut sebesar $95,22 \pm 3,09 \%$ dan 95,14 $\pm 4,26 \%$. Dari penelitian ini dapat disimpulkan bahwa piroksikam dapat dibuat dalam bentuk sediaan ODT karena menghasilkan sediaan tablet dengan sifat fisik yang baik kecuali pada uji kerapuhan. Formula yang dipilih yaitu formula 2, karena waktu hancur dan disolusi tablet lebih baik dibandingkan dengan formula 1 .
\end{abstract}

Kata kunci: piroksikam, Avicel PH 102, Orally Disintegrating (ODT), kempa langsung 


\begin{abstract}
Piroxicam is used to treat analgetic and antiinflammatory disease that is often experienced by elderly who have difficulty in swallowing and has problems on solubility. The solution that can be done to resolve the issue is with the preparation of Orally Disintegrating Tablet (ODT). Avicel PH 102 is disintegran which is used as a constituent of ODT. The purpose of this research is to develop piroxicam into ODT form dosage and to know the better formula from the two formulas used. The making method of the ODT is by direct compression. The variation of PH Avicel 102 concentration used for formula 1 is $15 \%$ and for formula 2 is 20\%. Before doing the orally disintegrating tablet formulation, spectrophotometry UV-Vis verification including specificity, precision, and accuracy must be done. Tablet from the formulation results were checked it's physical characteristics which include tablet identification, fragility, hardness, thickness, disintegration time, form and size of the tablets, hedonic test, disolussion rate, and assay. The results of the verification from the three trials are eligible with the requirement so the test method can be said to be valid. The results from the tablet's physical test are eligible with the requirement except the fragility test. The dissolution rate data and pirioxicam tablet's assay are eligible with the requirement that stated in Farmakope Indonesia $V$ which is the dissolution rate isn't less than $75 \%(Q+5 \%)$. The assay's results from $F 1$ and $F 2$ continously are, $95.22 \pm 3.09 \%$ dan $95.14 \pm 4.26 \%$. From this research, it can be concluded that piroxicam is suitable to be made in ODT dosage form because it produces tablet with good physical properties except for fragility test and the preferred formula is formula 2, because the disintegration time and the dissolution rate is better than formula 1.
\end{abstract}

Keywords: Piroxicam, Avicel PH 102, Orally Disintegrating (ODT), Direct Compression.

\title{
PENDAHULUAN
}

Piroksikam merupakan obat golongan Non Steroidal Anti Inflammatory Drugs (NSAID) turunan oksikam yang berkhasiat sebagai analgetik dan antiinflamasi pada pengobatan rheumatoid arthritis, osteoarthritis, dan penyakit musculoskeletal. Penyakit-penyakit tersebut sering dialami oleh kalangan lansia yang mempunyai kesulitan menelan. Upaya yang dapat dilakukan untuk mengatasi masalah tersebut yaitu dikembangkan bentuk sediaan Orally Disintegrating Tablet (ODT). ODT merupakan sediaan solid yang terdisintegrasi dan terlarut secara cepat (10-45 detik) dalam rongga mulut tanpa memerlukan air minum untuk membantu menelan (Setyawan et al., 2010). Pembuatan ODT, selain untuk mempermudah menelan juga bertujuan untuk menurunkan efek samping piroksikam yaitu gangguan lambung. Sediaan ODT dapat mencegah kontak piroksikam dengan dinding lambung, karena akan segera melarut setelah sediaan hancur di mulut (Binarjo \& Khotimah, 2017).

Pembuatan sediaan ODT memerlukan sifat obat yang mudah terdisintegrasi. Disintegran merupakan bahan tambahan yang penting pada formula tablet ODT, karena 
dapat menyebabkan tablet pecah ketika kontak dengan cairan sehingga akan meningkatkan kecepatan disolusinya. Avicel PH 102 merupakan salah satu bahan disintegran yang digunakan pada kempa langsung dan merupakan derivat selulosa. Avicel PH 102 sering digunakan pada metode kempa langsung karena mempunyai sifat alir yang baik, selain itu juga memiliki mekanisme wicking. Wicking action akan menyebabkan air berpenetrasi ke dalam pori-pori tablet, kemudian akan mengakibatkan tablet pecah. Avicel PH 102 juga dapat meningkatkan kecepatan disolusi piroksikam pada sediaan ODT dengan konsentrasi sebesar 15\% (Setyawan et al, 2010). Penelitian ini bertujuan untuk mengetahui formulasi piroksikam yang terbaik sebagai sediaan ODT.

\section{METODE PENELITIAN}

\section{Bahan dan Alat}

Bahan

Bahan utama yang digunakan dalam penelitian ini adalah serbuk piroksikam dan untuk bahan penyusun lainnya berupa zat tambahan avicel PH 102 (Bratacem), mannitol (Bratacem), Spray dried lactose (SDL) dan Mg stearate (Bratachem).

Alat

Alat penelitian yang digunakan antara lain mesin tablet single punch (Korch tipe PE 246 src, Jerman), hardness tester (Mosanto®), Friability tester (Erweka ${ }^{\circledR}$ friabilator abrasive tester tipe T.AP., Jerman), Dissolutiontester, Spektrofotometer UV (Genesys 10S), timbangan analitik (Ohaus TM AR2140) dan alat gelas (Pyrex).

\section{Jalannya Penelitian}

Verifikasi Spektrofotometri UV-Vis

\section{Spesifisitas}

Sebanyak 10 mg standar piroksikam ditimbang dan dilarutkan dalam $100 \mathrm{~mL} \mathrm{HCl}$ metanol 0,1 N, sedangkan untuk sampel ditimbang sebanyak $100 \mathrm{mg}$ dan dilarutkan dengan $\mathrm{HCl}$-metanol 0,1 $\mathrm{N}$ hingga $100 \mathrm{~mL}$. Larutan disaring, kemudian dari larutan stok dibuat larutan standar dan larutan sampel dengan konsentrasi $5 \mu \mathrm{g} / \mathrm{mL}$. Kedua larutan tersebut masing-masing dibaca pada $\lambda$ 200-500 $\mathrm{nm}$ menggunakan spektrofotometri UV (Garg et al., 2014).

Presisi

Uji presisi dilakukan dengan membaca absorbansi dari tiga konsentrasi larutan standar piroksikam konsentrasi 3,5 , dan $7 \mu \mathrm{g} / \mathrm{mL}$ pada $\lambda$ maksimum menggunakan alat spektrofotometer UV. Pembacaan absorbansi masing-masing konsentrasi dilakukan 
sebanyak 3 kali dalam satu hari. Hasil absorbansi yang diperoleh kemudian dihitung nilai Mean, SD, dan RSD-nya (Garg et al., 2014).

Akurasi

Uji akurasi dilakukan dengan metode penambahan standar. Sampel dengan kadar $5 \mu \mathrm{g} / \mathrm{mL}$ dianalisis menggunakan spektrofotometri UV. Kemudian standar dengan konsentrasi $80 \%, 100 \%$, dan 120\% ditambahkan ke dalam sampel dan dianalisis. Selisih kedua hasil dibandingkan dengan kadar sebenarnya (hasil yang diharapkan). Perolehan kembali dapat ditetapkan dengan rumus 1 (Riyanto, 2014).

$\%$ perolehan kembali $=\frac{(C 1-C 2) x 100 \%}{c 3}$

Keterangan :

$\mathrm{C} 1=$ konsentrasi total sampel yang diperoleh dari pengukuran

$\mathrm{C} 2$ = konsentrasi sampel yang sebenarnya

C3 = konsentrasi analit yang ditambahkan

Formula

Formula ODT tersaji pada table I, mengandung $20 \mathrm{mg}$ piroksikam tiap tablet. Dibuat 2 formula dengan kadar avicel PH 102 yang berbeda-beda. Setiap formula dibuat 500 tablet.

Tabel I. Formula ODT Piroksikam

\begin{tabular}{lcc}
\hline \multicolumn{1}{c}{ Komposisi } & F1 & F2 \\
\hline Piroksikam & $20 \mathrm{mg}$ & $20 \mathrm{mg}$ \\
Mannitol & $104 \mathrm{mg}$ & $104 \mathrm{mg}$ \\
Spray Dried Lactose & $35 \mathrm{mg}$ & $40 \mathrm{mg}$ \\
Avicel PH102 & $15 \%$ & $20 \%$ \\
Mg stearate & $0,5 \%$ & $0,5 \%$ \\
\hline
\end{tabular}

Cara Pembuatan

Semua bahan kecuali Mg Stearat ditimbang sesuai formula untuk 500 tablet kemudian dicampur hingga homogen selama 15 menit. Setelah homogen, $\mathrm{Mg}$ stearat ditambahkan dan dicampur selama 5 menit dalam tumbling mixer.

Evaluasi Mutu Tablet

Sifat alir

Uji sifat alir campuran serbuk dilakukan menggunakan alat corong. Sebanyak 25 gram serbuk dimasukkan ke dalam corong yang sebelumnya sudah ditutup bagian 
bawahnya. Penutup corong dibuka kemudian dicatat waktu yang dibutuhkan untuk semua serbuk mengalir. Syarat waktu alir granul yang baik yaitu untuk 100 gram serbuk tidak lebih dari 10 detik (USP, 2015).

Uji Kerapuhan

Uji kerapuhan tablet dilakukan dengan menggunakan alat friability tester. Sebanyak 32 tablet dibebasdebukan, ditimbang berat awalnya, kemudian dimasukkan ke alat uji yang diputar dengan kecepatan $25 \mathrm{rpm}$. Setelah itu tablet dibebasdebukan lagi dan ditimbang bobot akhirnya (USP, 2005). Syarat kerapuhan untuk ODT yaitu kurang dari 1\% (Izza et al., 2014).

\section{Uji Kekerasan}

Uji kekerasan dilakukan dengan 6 tablet dari masing-masing formula menggunakan alat hardness tester. Tablet yang akan diuji diletakkan pada ujung alat lalu alat diputar hingga tablet pecah atau hancur. Syarat kekerasan ODT yang baik adalah $3-5 \mathrm{~kg} / \mathrm{cm}^{2}$ (Panigrahi \& Behera, 2010).

\section{Uji Waktu Hancur}

Uji waktu hancur dilakukan dengan alat disintegration tester. Media yang digunakan adalah air dengan suhu $37^{\circ} \mathrm{C} \pm 2^{\circ} \mathrm{C}$. Alat dihentikan setelah seluruh tablet pada masing-masing tabung hancur sempurna dan diamati waktu hancurnya (Depkes RI, 2014). Untuk tablet ODT, syarat waktu hancurnya adalah tidak lebih dari 3 menit (Departement of Health, 2009).

Uji Bentuk dan Ukuran Tablet

Bentuk dan ukuran tablet dapat digambarkan secara dimensi, dapat dipantau dan dikontrol. Ukuran dan bentuk tablet ditentukan dengan merancang pengaturan pada mesin cetak tablet saat proses kompresi (Uddin et al., 2015).

Uji Ketebalan Tablet

Sebanyak 6 tablet dari setiap formula diukur diameter dan ketebalannya menggunakan jangka sorong. Kecuali dinyatakan lain, diameter tablet tidak lebih dari tiga kali dan tidak kurang dari 1 1/3 (satu sepertiga) kali tebal tablet (Depkes RI, 1979).

Identifikasi Tablet

Uji identifikasi dilakukan dengan spektrum serapan UV, dengan cara membuat larutan sampel piroksikam dengan konsentrasi $10 \mu \mathrm{g} / \mathrm{mL}$ menggunakan pelarut asam klorida $\mathrm{p}$ dalam methanol $\mathrm{p}$ (1 dalam 1200). Panjang gelombang maksimum dan minimum dibandingkan dengan panjang gelombang piroksikam teoritis (Depkes RI, 2014). 
Uji Homogenitas

Semua bahan kecuali Mg Stearat dicampur hingga homogen menggunakan mixer dengan kecepatan $50 \mathrm{rpm}$. Campuran diambil $100 \mathrm{mg}$ di 5 tempat bagian mixer pada waktu 15, 30, dan 45 menit. Sampel dilarutkan dalam asam klorida p dalam methanol $\mathrm{p}$ (1 dalam 1200), disaring lalu dibaca pada $\lambda$ maksimum (Depkes RI, 2014).

Uji Penetapan Kadar

Uji penetapan kadar piroksikam dilakukan dengan menggunakan metode spektrofotometri UV. Larutan baku dan larutan uji dengan konsentrasi $5 \mu \mathrm{g} / \mathrm{mL}$ dibaca serapannya pada $\lambda \pm 334 \mathrm{~nm}$ menggunakan asam klorida-metanol $0,1 \mathrm{~N}$ sebagai blangko. Kadar piroksikam yang dipersyaratkan oleh Farmakope V (2014) adalah tidak kurang dari $90 \%$ dan tidak lebih dari $110 \%$. Jumlah piroksikam yang terkandung dapat dihitung dengan rumus 2 dan 3 (Depkes RI, 2014 ).

$$
\text { Konsentrasi }(\mathrm{C})=\mathrm{Au} / \mathrm{As} \ldots \ldots . .(2)
$$

Keterangan :

$\mathrm{C} \quad=$ konsentrasi piroksikam dalam $\mathrm{mg} / \mathrm{mL}$

$\mathrm{Au}=$ serapan larutan uji

As = serapan larutan baku

$$
\text { Kadar }=\frac{\text { Konsentrasi (c) } \times 100 \mathrm{~mL} \times \mathrm{FP}}{\mathrm{mg} \text { sampel }} \times 100 \% \ldots \text { (3) }
$$

Uji Hedonik (Tanggapan Rasa)

Uji hedonik dilakukan oleh 6 responden yang dipilih secara acak. Tablet piroksikam dirasakan selama 10 detik kemudian responden memberikan tanggapan rasa berupa tingkat kepahitan dengan skala 0-3 (tidak pahit, sedikit pahit, pahit, dan sangat pahit) (Wagh et al., 2009; Rabbani et al., 2017).

Analisis Data

Data hasil uji yang dilakukan pada semua tahapan dibandingkan dengan dengan persyaratan untuk tablet piroksikam pada Farmakope Indonesia, CPOB, maupun literatur lainnya.

\section{HASIL DAN PEMBAHASAN}

\section{Verifikasi Spektrofotometri UV-Vis}

Uji verifikasi yang dilakukan pada penelitian ini yaitu meliputi tiga uji diantaranya spesifisitas, presisi dan akurasi. Uji ini dilakukan untuk memastikan metode penelitian yang tertera pada kompendia (Farmakope Indonesia \& USP) valid dan dapat digunakan dalam penelitian ini. Berdasarkan hasil uji untuk spesifisitas dengan membandingkan 
antara $\lambda$ sampel dengan $\lambda$ standar diperoleh hasil yang sama sehingga dikatakan uji spesifisitas memenuhi syarat. Uji presisi diperoleh hasil berupa nilai RSD dari ketiga konsentrasi kurang dari $2 \%$ dan dinyatakan memenuhi syarat, dan untuk uji akurasi diperoleh \% recovery masuk dalam range 98-102\% sehingga dikatakan memenuhi syarat seperti tersaji pada Tabel II.

Evaluasi Mutu Tablet

Sifat alir

Syarat waktu alir yang baik adalah tidak lebih dari $10 \mathrm{~g} /$ detik. Kecepatan alir untuk formula 1 dan 2 pada penelitian ini jika dibandingkan dengan peneliatan Setyawan (2010) dikatakan lebih baik dan memenuhi syarat yang telah ditetapkan sehingga bisa dilanjutkan untuk pembuatan tablet secara kempa langsung. Hasil waktu alir dapat dilihat pada Tabel III.

Tabel II. Hasil uji verifikasi metode spektrofotometri UV penentuan kadar

\begin{tabular}{|c|c|c|c|c|c|}
\hline & \multicolumn{3}{|c|}{ Uji presisi (\%RSD) } & $\begin{array}{c}\text { Uji akurasi } \\
(\% \text { Recovery }) \pm \text { SD }\end{array}$ & $\begin{array}{c}\text { Uji spesifisitas } \\
(\lambda \text { Maks })\end{array}$ \\
\hline \multirow[t]{3}{*}{ Hasil uji } & \multicolumn{3}{|c|}{$\operatorname{Kadar}(\mu \mathrm{g} / \mathrm{ml})$} & & 333,80 \\
\hline & 3 & 5 & 7 & $102,10 \% \pm 7,98$ & ( $\lambda$ sampel) \\
\hline & $1,43 \%$ & $1,13 \%$ & $0,92 \%$ & & \\
\hline \multirow[t]{2}{*}{ Syarat } & \multirow{2}{*}{\multicolumn{3}{|c|}{$<2 \%$}} & $98-102 \%$ & 333,80 \\
\hline & & & & & ( $\lambda$ Standar) \\
\hline Keterangan & \multicolumn{3}{|c|}{ Memenuhi syarat } & Memenuhi syarat & Memenuhi syarat \\
\hline
\end{tabular}

Uji kerapuhan

Hasil uji kerapuhan tablet ODT formula 1 adalah 27,3\% (Avicel PH 102 sejumlah 15\%), sedangkan formula 2 adalah 2,04\% (Avicel PH 102 sejumlah 20\%). Hasil tersebut menunjukkan apabila kadar Avicel PH 102 meningkat maka akan meningkatkan kekerasan sehingga dapat menurunkan kerapuhan. Apabila dibandingkan dengan penelitian Setyawan et al (2010) yang menggunakan avicel 15\% memiliki nilai kerapuhan $1,25 \%$. Kedua uji kerapuhan pada formula di atas tidak memenuhi syarat yang ditentukan yaitu kurang dari 1\% (Izza et al., 2014).

Hasil tersebut kemungkinan disebabkan karena perbedaan jumlah Spray dried lactose, tidak adanya penambahan pengikat karena menggunakan kempa langsung dan dipengaruhi oleh besarnya tekanan pada saat pencetakan tablet. Salah satu cara untuk mengurangi tingginya nilai kerapuhan dapat diatasi dengan meningkatkan tekanan pada saat pencetakan tablet. Hasil uji kerapuhan dapat dilihat pada Tabel III. 


\section{Uji kekerasan}

Hasil uji kekerasan pada formula kemungkinan dipengaruhi oleh konsentrasi avicel PH 102 yang ditambahkan. Hal tersebut dibuktikan dari formula 2 pada penelitian ini yang mengandung 20\% avicel PH 102 memiliki kekerasan yang lebih besar dibandingkan dengan hasil yang diperoleh pada penelitian Setyawan (2010). Hasil uji kekerasan pada penelitian ini khusunya formula 2 memenuhi persyaratan kekerasan ODT yaitu 3-5 kg (Panigrahi \& Behera, 2010). Hasil uji kekerasan dapat dilihat pada Tabel III.

\section{Uji Waktu Hancur}

Waktu hancur untuk formula 1 dan 2 sebesar 28 detik dan 40 detik. Hasil tersebut memenuhi persyaratan uji waktu hancur kurang dari 1 menit (Kundu \& Sahoo, 2008), walaupun hasil yang didapatkan lebih besar dari penelitian yang dilakukan oleh Setyawan (2010) yaitu untuk ODT dengan konsentrasi 15\% Avicel PH 102 waktu hancurnya 18,33 detik.

Uji bentuk dan ukuran tablet

Tablet piroksikam dilihat bentuknya secara visual memiliki bentuk yang bulat, keadaan permukaan yang halus dan tidak mengkilap. Tablet ini tergolong baik karena memiliki permukaan yang rata, halus, tidak kotor, dan warnanya homogen yaitu kuning. Tablet piroksikam memiliki ukuran diameter $0,9 \mathrm{~cm}$ dan ketebalan $0,3 \mathrm{~cm}$.

\section{Uji ketebalan tablet}

Ketebalan tablet dipengaruhi oleh beberapa hal yaitu tekanan pada saat mencetak tablet, jumlah massa yang diisikan pada ruang cetak tablet dan kerapatan massa tablet yang dicetak, sedangkan diameter tablet dapat dipengaruhi oleh ukuran ruang cetak tablet. Hasil yang tertera pada Tabel VI menunjukkan bahwa kedua formula memenuhi syarat ketebalan tablet yaitu diameter tablet tidak lebih dari 3 kali tebal tablet dan juga kurang dari 1 1/3 kali tebal tablet (Depkes RI, 1979). Hasil uji ketebalan tablet dapat dilihat pada Tabel III. 
Tabel III. Hasil evaluasi mutu ODT piroksikam

\begin{tabular}{lccc}
\hline Uji Sifat Fisik & Formula 1 & Formula 2 & Syarat \\
\hline Waktu Alir & 0,93 detik & 0,85 detik & 100 gram kurang dari 10 detik \\
Kerapuhan & $27,3 \%$ & $2,04 \%$ & $<1 \%$ \\
Kekerasan & $2,58 \pm 7,40 \mathrm{~kg}$ & $3,00 \pm 5,80 \mathrm{~kg}$ & $3-5 \mathrm{~kg}$ \\
Waktu & 28 detik & 40 detik & $<1$ menit \\
hancur & & & \\
Ketebalan & $0,3 \pm 0,00 \mathrm{~cm}$ & $0,3 \pm 0,00 \mathrm{~cm}$ & $3 \times$ tebal tablet $<\mathrm{D}<11 / 3 \times$ tebal \\
Disolusi & $78,04 \%$ & $81,33 \%$ & $75 \%$ \\
Penetapan & $95,22 \pm 3,09 \%$ & $95,14 \pm 4,26 \%$ & $90-110 \%$ \\
Kadar & & & \\
\hline
\end{tabular}

Identifikasi kandungan tablet

Hasil pengukuran panjang gelombang maksimum dari tablet adalah 334,6 nm dan panjang gelombang minimumnya adalah $245 \mathrm{~nm}$. Tablet ODT terbukti mengandung piroksikam karena hasil tersebut menunjukkan kedekatan pada panjang gelombang yang ditetapkan pada Farmakope Indonesia edisi V (2014) yaitu panjang gelombang maksimal $334 \mathrm{~nm}$ dan panjang gelombang minimal $243 \mathrm{~nm}$.

Uji homogenitas

Tujuan dari uji ini adalah untuk mengetahui waktu optimal dalam menghomogenkan campuran serbuk. Dikatakan homogen jika nilai CV yang diperoleh kurang dari $5 \%$. Nilai CV yang diperoleh dari percobaan ini adalah $4,34 \%$ pada menit ke-15 untuk formula 1, sedangkan untuk formula Hasil tersebut menyimpulkan bahwa mixing pada menit ke-15 telah diperoleh campuran yang homogen baik pada formula 1 maupun formula 2.

Uji Disolusi

Disolusi untuk formula 1 dan 2 sebesar 78,04\% dan 81,33\%. Hasil tersebut memenuhi persyaratan disolusi untuk tablet piroksikam yaitu tidak kurang dari $75 \%$ (Q $+5 \%$ ) dari jumlah yang tertera pada etiket dalam waktu 40 menit (Farmakope Indonesia edisi V, 2014). Namun hasil yang didapatkan lebih rendah dari penelitian yang dilakukan oleh Setyawan (2010) yaitu untuk ODT dengan konsentrasi 15\% Avicel PH 102 disolusinya $88,63 \%$.

\section{Uji Penetapan Kadar}

Hasil uji penetapan kadar untuk formula 1 dan 2 sebesar 95,22 \pm 3,09\% dan 95,14 $\pm 4,26 \%$. Farmakope Indonesia V mensyaratkan bahwa setiap tablet piroksikam mengandung tidak kurang dari $90,0 \%$ dan tidak lebih dari $110,0 \%$ dari jumlah yang 
tertera pada etiket, sehingga penetapan kadar kedua formula ODT piroksikam pada penelitian ini memenuhi persyaratan menurut Farmakope Indonesia V (2014).

Uji Hedonik (Tanggapan Rasa)

Dari 6 panelis menyatakan bahwa tablet piroksikam memiliki rasa seperti tersaji pada Table IV.

Tabel IV. Hasil uji hedonik ODT piroksikam

\begin{tabular}{cccc}
\hline No & Tidak pahit & Pahit & Sangat pahit \\
\hline 1 & $\checkmark$ & - & - \\
2 & $\checkmark$ & - & - \\
3 & - & $\checkmark$ & - \\
4 & $\checkmark$ & - & - \\
5 & - & $\checkmark$ & - \\
6 & $\checkmark$ & - & - \\
\hline
\end{tabular}

Berdasarkan data dari Tabel IV tersebut menunjukkan 4 responden menyatakan tidak pahit dan 2 relawan menyatakan pahit terhadap rasa tablet piroksikam, sehingga dikatakan $66 \%$ menyatakan tidak pahit terhadap tablet piroksikam . Uji tanggap rasa ini dilakukan untuk menilai apakah tablet piroksikam yang dihasilkan dapat diterima oleh panelis dengan parameter rasa. Uji kesukaan adalah metode uji yang digunakan untuk mengukur tingkat kesukaan pada suatu produk dengan menggunakan lembar penilaian (Anonim, 2006).

\section{KESIMPULAN}

Formula pada penelitian ini menghasilkan sediaan ODT yang baik namun tidak memenuhi persyaratan uji kerapuhan. Formula yang dipilih yaitu formula 2 yang mengandung 20\% avicel PH 102 dengan sifat fisik yang lebih baik dibandingkan formula 1 yang mengandung 15\% avicel PH 102.

\section{DAFTAR PUSTAKA}

Anonim, 2006, Standar Nasional Indonesia Petunjuk Pengujian Organoleptik dan atau Sensori, Jakarta: Badan Standardisasi Nasional

Binarjo, A., dan Khotimah, H., 2017, Disolusi Kapsul Dispersi Padat Piroksikam-PEG 6000 selama Penyimpanan, IJPST, 4(1): 18-26

Depkes RI, 1979, Farmakope Indonesia Edisi III, Departemen Kesehatan Republik Indonesia: Jakarta, hal. 6 
Depkes RI, 2014, Farmakope Indonesia Edisi V, Departemen Kesehatan Republik Indonesia: Jakarta, hal. 1031, 1609, 1613.

Departemen of Health, 2009, British Pharmacopeia, The Departement of Health, London

Garg, V., Singh, H., Singh, S, K., 2014, Development and validation of A Sensitive U.V. Method For Piroksikam: Application for Skin Permeation Studies, International Journal of Recent Scientific Research, 5(5): 980-983

Izza, A., Khawla, A., Vincent, Hli., 2014, Fast Dissolving Tablet, US Patent.

Kundu, S. and Sahoo, P. K., 2008, Recent Trends in The Deelopment of Orally Disintegrating Tablets Technology, Pharma Times, Vol 40, No 4

Panigrahi R. and Behera, S., 2010, A Review of Fast Dissolving Tablets, Webmed Central, 1 (9): 117

Rabbani, F., Husni, P., Hartono, K., 2017, Formulasi Tablet Hisap Ekstrak Kering Daun Sirih Hijau (Piper betle L), Farmaka, 15(1): 190

Riyanto, 2014, Validasi dan Verifikasi Metode Uji, Deepublish: Yogyakarta

Setyawan, D., Widjaja, B., Ningtyas, Z. F., 2010, Pengaruh Avicel Terhadap Karakteristik Fisik dan Laju Disolusi Orally Disitegrating Tablet Piroksikam dengan Metode Cetak Langsung, Majalah Ilmu Kefarmasian, 7(1): 9-16

Uddin, M.S., Al-mamun. A., Tasnu, T., Asaduzzaman, M., 2015, In-process and Finished Products Quality Control Test for Pharmaceutical Tablets According to Pharmacopoeias, Journal of Chemical and Pharmaceutical Research, 7(9): 180-185

USP, 2005, The United States of Pharmacopeia $28^{\text {th }}$ Ed, Electronic version, United states, 2745

USP, 2015, The United States Pharmacopeia, $38^{\text {th }}$ Ed, Elektronic Version, United States, 1329

Wagh, V. D., Ghadlinge, S. V., 2009, Taste Masking Methods and Massking in Oral Pharmaceuticals: Current Perspectives, Journal of Pharmacy Research, 2(6): 1049-10. 